\title{
The world price of exchange risk in the Pacific Basin equity markets
}

\author{
PETER SHYAN-RONG CHOU, YIN-CHING JAN* + and \\ MAO-WEI HUNG
}

Department of Finance Operations, National Kaohsiung First University of Science and Technology. 1, University Road, Yuanchau, Kaohsiung, Taiwan, ROC, $\$$ Department of Industrial Engineering and Management, National Chin-Yi Institute of Technology. 35, Lane 215, ChungShan Road, Taiping City, Taichung, Taiwan, ROC and $\S$ Department of International Business, National Taiwan University. 50, Lane 144, Keelung Road, Section 4, Taipei, Taiwan, ROC

This paper investigates whether the foreign exchange risk is priced in the Pacific Basin equity markets. The test was performed in the conditional version which allows the world prices of market risk and exchange risk to vary over time. Being parsimonious, a principal component analysis is taken on these Pacific Basin interest rates to extract the common exchange rate factors. The results show that the international asset pricing model with exchange risk premia is better than the international asset pricing model without exchange risk premia to describe the Pacific Basin stock returns. This implies the world prices of exchange risk are present in the Pacific Basin equity markets.

\section{INTRODUCTION}

Accurate models of international asset pricing are vital to understand and predict the behaviour of international investment in an increasingly integrated world. Although Solnik (1974a), Stulz (1981) and Adler and Dumas (1983) had successfully extended the domestic Asset Pricing Model (APM) to international APM,${ }^{1}$ the empirical tests of their models did not provide convincing evidence to support the international APM. There are several approaches that can be used to test the international APM. First, the unconditional version of the international APM, in which the second moments are constant and the market prices of risk are unspecified, can be used. Solnik (1974b) and Stehle (1977) found evidence in favour of the international Capital Asset Pricing Model $(\mathrm{CAPM}),{ }^{2}$ but in their work national factors also played an important role in determining the price behaviour of equity returns. Wheatley (1988) and Cumby (1990) provided little evidence against the unconditional version of the international consumption-base d APM described in Stulz (1981). ${ }^{3}$ Second, a more recent approach is to use the conditional form. This formulation lets the risk premium or market price of the risk vary over time. For example, Harvey (1991) found that the international CAPM with time-varying risk premium was useful in characterizing the dynamics of cross-section expected returns in most developed countries, but it did not perform well for other developed countries. Third, one can specify second moment behaviour and assume that the coefficient of risk aversion is constant. The evidence of Engel and Rodrigues (1989) and Thomas and Wickens (1993) showed that the international CAPM performs much better when the covariance matrix is not constant over time, but provided little explanatory power for expected relative rates of return.

Although the above studies did not reject the international CAPM, the results seemed inconsistent with the

\footnotetext{
* Corresponding author.

${ }^{1}$ See the review of Stulz (1994).

2 The international CAPM was developed by Solnik (1974a) under the assumption of independence between exchange and market risks.

${ }^{3}$ In contrast to the results for the full sample, from January 1974 to December 1987, Cumby found that observed real equity returns are consistent with the model during the 1980 s. 
observed cross-section rates of return for some markets. This phenomenon has led to empirical research to determine whether there are other risk premia which impact the behaviour of equity returns. In fact, the foreign exchange premium, which is acquired under the deviation of Purchasing Power Parity (PPP), has already been presented in the international APM of Adler and Dumas (1983). ${ }^{4}$ However, the unobservable wealth weighted risk tolerance, on which the weights on the covariances of asset returns with inflation depend, make the model difficult to test. The work of Dumas (1994) and Dumas and Solnik (1995) substituted the interest rate for the inflation rate and successfully derived world prices of foreign exchange risk from the wealth weighted risk tolerance. While their evidence supported the existence of foreign exchange risk premia, there would be too many parameters to get risk premia estimates stable under the conditional approach, so only a small number of countries could be examined simultaneously. Another simplification is to aggregate the exchange rate factor by weighted average, e.g., Ferson and Harvey (1993) and Harvey (1995). However, they did not provide an adequate theoretical basis for their choice of weights.

This study takes a principal component analysis on the interest rates to construct the exchange rate factors. This method avoids the shortcomings of the weighted average approach and makes the model parsimonious. In fact, the principal component analysis we used is similar in spirit to the international Arbitrage Pricing Theory (APT) postulated by Solnik (1983). If the financial markets are integrated, any economical shocks would influence endogenous variables such as exchange rates and interest rates. For instance, significant deficit fiscal policy by a government may increase the interest rate, leading to an appreciation of this country's currency. Because there are so many shocks and so many countries, in which shocks could originate, one cannot identify these factors directly. Conversely, with the principal component analysis, these factors can be reasonably extracted.

The aim of this study is to test whether the foreign exchange risk is priced in Pacific Basin equity markets by international APM with principal component analysis. If the risk is priced, hedging will be valuable to investors; see, e.g. Perold and Schulman (1988). To take advantage of potential diversification benefits from investing in Pacific Basin markets, we need to know whether there exists foreign exchange risk in this region.

The empirical evidence shows that the international APM with exchange risk premia performs better than the international APM without exchange risk premia, implying that the foreign exchange risk is priced in Pacific Basin equity markets. The paper is organized as follows.
Section II outlines the methodology. Section III describes the data; section IV presents the empirical results. Some concluding remarks are presented in the final section.

\section{METHODOLOGY}

If there are $L+1$ countries and a set of $N=n+L+1$ assets which compose of $n$ equities and $L+1$ nominal bank deposits, the international APM developed by Adler and Dumas (1983) can be written as:

$$
r_{i}=\left(1-1 / \alpha^{m}\right) \frac{\sum_{i}\left(1-\alpha^{l}\right) w^{l} \sigma_{i, \pi}^{l}}{\sum_{l}\left(1-\alpha^{l}\right) w^{l}}+\left(1 / \alpha^{m}\right) \sum_{k=1}^{N} w_{k}^{m} \sigma_{i, k}
$$

where $r_{i}$ is the excess return on the security $i$, which subtracts the risk-free rate on the numeraire currency, and $\alpha^{m}=\sum_{l} w^{l} \alpha^{l} / \sum_{l} w^{l}$ is the average individual's risk tolerance, $\alpha^{l}$, weighted by their own wealth, $w^{l}$. While $w_{k}^{m}$ is the weight on the market portfolio, $\sigma_{i, \pi}^{l}$ and $\sigma_{i, k}$ are the covariances of security $i$ with the investors' rate of inflation and market portfolio, respectively. Unfortunately, the first term on the right-hand side is unobservable. To get an empirical asset pricing model, the first term must be aggregated under the assumption that investors from the same country use the same deflator and therefore have the same covariance term $\sigma_{i, \pi}$ across countries. Then, one has the multi-beta CAPM:

$$
r_{i}=\left(1-1 / \alpha^{m}\right) \sum_{j=1}^{L} y_{j} \sigma_{i, \pi}+\left(1 / \alpha^{m}\right) \sum_{k=1}^{N} w_{k}^{m} \sigma_{i, k}
$$

where $y_{j}=\sum_{l}\left(\left(1-\alpha^{l}\right) w^{l} / \sum_{l}\left(1-\alpha^{l}\right) w^{l}\right)$ is the national wealth weighted average risk tolerance, where the first summation is over all the investors of the same country and the summation in the denominator is over all the world's investors. Hence, there exist $L$ risk premia concerned for inflation rate and one risk premium for the world market portfolio. When the prices of risk are allowed to be timevarying, the conditional version of Equation 2 satisfies

$$
\begin{aligned}
E\left(r_{i t} \mid \Omega_{t-1}\right) & =\sum_{j=1}^{L} \lambda_{j, t-1} \operatorname{cov}\left(r_{i t}, r_{j t} \mid \Omega_{t-1}\right) \\
& +\lambda_{m, t-1} \operatorname{cov}\left(r_{i t}, r_{m t} \mid \Omega_{t-1}\right)
\end{aligned}
$$

where $E(\cdot)$ is expectation operator, $r_{i t}$ is the excess return on security $i$ from time $t-1$ to $t, r_{m t}$ is the excess return on the world market portfolio, $r_{j t}$ is the excess return on the currency deposit of country $j$, and $\Omega_{t-1}$ is the information set. The coefficient $\lambda_{j, t-1}$, which is equal to $\left(1-\left(1 / \alpha^{m}\right)\right) y_{j}$, represents the time-varying world prices of exchange risk, and the coefficient $\lambda_{m, t-1}$, which is equal to $1 / \alpha^{m}$, repre-

\footnotetext{
${ }^{4}$ The foreign exchange premium, which was also presented in Solnik (1974a) and Stulz (1981), was designated as inflation premium in Adler and Dumas (1983).
} 
sents the time-varying world price of market risk. We replace the inflation premium $\mathrm{O}_{i, \pi}$ with $\operatorname{cov}\left(r_{i t}, r_{j t} \mid \Omega_{t-1}\right)$, which is the conditional covariance of the excess return $r_{i t}$ and $r_{j t}$. The reasoning of this substitution lies in the low frequency and insensitivity of the inflation rate. Consequently, this substitution makes the international APM of Adler and Dumas (1983) similar to the $n+1$ funds theorem of Solnik (1974a).

To test this conditional version of the international APM, one needs to know how the investors perceive the world prices of exchange risk and market risk. It is assumed that the information set $\Omega_{t-1}$ is generated by a vector of $\ell$ predetermined instrumental variables $z_{t-1}$. As a result, these variables $z$ can serve as proxies for the state variables. It is also assumed that there exists a linear relationship between the world prices of risk and these state variables, i.e.,

$$
\begin{aligned}
\lambda_{j, t-1} & =z_{t-1} \delta_{j} \\
\lambda_{m, t-1} & =z_{t-1} \delta_{m}
\end{aligned}
$$

where the $\delta_{j}$ and $\delta_{m}$ are $\ell$ time-invariant vectors of parameter. From the above assumption, Equation 3 becomes:

$$
\begin{aligned}
E\left(r_{i t} \mid z_{t-1}\right)= & \sum_{j=1}^{L} z_{t-1} \mathrm{~d}_{j} \operatorname{cov}\left(r_{i t}, r_{j t} \mid z_{t-1}\right) \\
& +z_{t-1} \delta_{m} \operatorname{cov}\left(r_{i t}, r_{m t} \mid z_{t-1}\right)
\end{aligned}
$$

If the exchange risks are not priced, the first term of the right-hand side of Equation 5 would disappear, which is the conditional form of Sharpe-Lintner asset pricing model. Following Dumas and Solnik (1995), the model that contains the prices of exchange risk is referred to as 'international', and the model that does not contain such terms is referred to as 'classic'.

Equation 5 satisfies the first-order conditions from a standard representative agent's discrete-time utility maximization problem (see Lucas, 1982), i.e.,

$$
\begin{aligned}
E\left(M_{t}\left(1+r_{f, t-1}\right) \mid z_{t-1}\right) & =1 \\
E\left(M_{t} r_{i t} \mid z_{t-1}\right) & =0
\end{aligned}
$$

where $\left.M_{t}\left(1-\sum_{j=1}^{L} z_{t-1} \delta_{j} r_{j t}-z_{t-1} \delta_{m} r_{m t}\right) / 1+r_{f, t-1}\right)$, which is the pricing kernel implied by the mean-variance theory of international asset pricing (see Hansen and Jagannathan, 1991), and $r_{f, t-1}$ is the conditionally risk-free rate on numeraire currency. Under rational expectation, Equation 6 satisfies:

$$
\begin{aligned}
e_{t} & =1-M_{t}\left(1+r_{f, t-1}\right) \\
h_{i t} & =M_{t} r_{i t}
\end{aligned}
$$

where $e_{t}$ and $h_{i t}$ are innovations. Taking a little algebra, Equation 7 becomes:

$$
\begin{aligned}
e_{t} & =\sum_{j=1}^{L} z_{t-1} \delta_{j} r_{j t}+z_{t-1} \delta_{m} r_{m t} \\
h_{i t} & =r_{i t}-r_{i t} e_{t}
\end{aligned}
$$

Let $\varepsilon_{t}=\left(e_{t}, h_{t}\right)$, Equation 6 implies $E\left(\varepsilon_{t} \mid z_{t-1}\right)=0$. Therefore, Hansen's (1982) generalized method of moment (GMM) estimation can be used to estimate these multiple equations. $^{5}$

If there are $L+1$ portfolios to be tested, there will be $\not L+1)$ parameters which need to be estimated. The number of parameters may be too large to achieve stability in this model. For the reasons of stability and parsimony, a principal component analysis to the interest rates is taken and the $L$ interest rates reduced to $p$ factors. When the factor analysis is taken, the factor scores obtained by the weighted least square method are equivalent to the principal components. Hence, the spirit of the principal component analysis in this step lies in extracting the common factors that influence those interest rates.

In order to test the adequateness of the conditional APM for Pacific Basin equity markets, Hansen's test of overidentifying restrictions can be used. For the $L+1$ equities to be tested, there will be $(L+2) \times \ell$ orthogonality conditions and $\ell \times(p+1)$ parameters. It follows that the $J$ statistic of Equation 8 is asymptotically distributed as chi-squared $\left(\chi^{2}\right)$ with the number of degrees of freedom equal to $\ell \times(L+1-p)$, which is the number of overidentifying restrictions.

\section{DATA AND SUMMARY STATISTICS}

In this study, six equity markets were taken into account: Hong Kong, Japan, Korea, Malaysia, Thailand and the USA. These data were drawn from the Pacific-Basin Capital Markets (PACAP) database, except for the US data which came from the German and International Financial (GERFIN) database. The market returns from the PACAP database were value weighted market returns with cash dividend reinvested, while the market return for the USA was the monthly rate of change of Standard and Poor's 500 Composite Share Index (S\&P500). The Morgan Stanley Capital International (MSCI) world index was treated as the world market portfolio. During this stage, we must assume that the MSCI world index is an efficient benchmark portfolio. If the MSCI world index is not efficient, there may be no relationship between the world price of market risk and the expected return. Moreover, empirical tests of the mean-variance efficiency of the MSCI world

\footnotetext{
${ }^{5}$ Based on Ferson and Foerster (1994), iterated GMM were used, which was proven to be superior to the two step GMM in a finite sample.
} 
index, as far as is known, have never refuted, e.g., Harvey and Zhou (1993). Available monthly data cover the period from April 1980 to December 1993. This period was chosen by most Pacific Basin countries to open their capital markets, and as a result, mitigate the effect of market segment on the pricing model.

All the market returns were measured in numeraire currency, the US dollar. The excess return on an equity market was the return on that market translated into dollars minus the dollar one-month nominally risk-free rate, which was the Fama/Bliss risk-free rate that came from the Center for Research in Security Price (CRSP). The excess return on a currency deposit was the one-month interest rate of that currency compounded by the rate of change of the exchange rate relative to the US dollar, minus the dollar one-month risk-free rate. The one-month interest rate of Japan was the
Euro money market middle rate that came from GERFIN, and the other four were money market rates which came from the International Monetary Fund (IMF).

The instrumental variables were common to all markets because we were interested in characterizing the common state variables across all markets. A number of researchers have found that some economical variables can capture the dynamics of equity return. Following Harvey (1991), the following economic variables were used as an information set: the world market return, the S\&P500 dividend yield (from the US Financial database, USFIN), the US yield spread between Moody's Baa and Aaa bonds (from USFIN), the excess return on a three month bill (from USFIN), and a dummy variable for the month of January.

Table 1 presents the summary statistics for the excess equity returns and instrumental variables. Panel A shows

Table 1a. Summary statistics for the market returns and instrumental variables: excess returns

\begin{tabular}{|c|c|c|c|c|c|c|c|c|c|}
\hline \multirow[b]{2}{*}{ Market } & \multirow[b]{2}{*}{ Mean } & \multirow[b]{2}{*}{ Std.dev } & \multirow[b]{2}{*}{ Reward/risk } & \multicolumn{6}{|c|}{ Autocorrelation } \\
\hline & & & & $\rho_{1}$ & $\rho_{2}$ & $\rho_{3}$ & $\rho_{4}$ & $\rho_{12}$ & $\rho_{24}$ \\
\hline $\mathrm{HK}^{\mathrm{a}}$ & 0.0158 & 0.094 & 0.168 & 0.094 & -0.064 & -0.018 & -0.108 & -0.015 & 0.030 \\
\hline $\mathrm{JP}$ & 0.0085 & 0.069 & 0.123 & 0.088 & -0.006 & 0.018 & 0.048 & 0.067 & -0.002 \\
\hline $\mathrm{KO}$ & 0.0105 & 0.074 & 0.142 & -0.000 & $0.174 *$ & -0.063 & 0.076 & 0.099 & 0.104 \\
\hline MY & 0.0115 & 0.081 & 0.142 & $0.179 *$ & 0.114 & -0.031 & 0.010 & -0.019 & 0.032 \\
\hline $\mathrm{TH}$ & 0.0176 & 0.078 & 0.225 & $0.207 *$ & 0.143 & 0.004 & -0.113 & 0.024 & -0.028 \\
\hline USA & 0.0038 & 0.035 & 0.110 & 0.016 & 0.020 & -0.100 & -0.020 & -0.119 & 0.025 \\
\hline World & 0.0047 & 0.043 & 0.109 & 0.053 & 0.031 & -0.022 & -0.005 & 0.017 & 0.131 \\
\hline
\end{tabular}

Table 1b. Summary statistics for the market returns and instrumental variables: instrumental variables

\begin{tabular}{|c|c|c|c|c|c|c|c|c|c|}
\hline \multirow[b]{2}{*}{ Variable } & \multirow[b]{2}{*}{ Mean } & \multirow[b]{2}{*}{ Std.dev } & \multirow[b]{2}{*}{ Reward/risk } & \multicolumn{6}{|c|}{ Autocorrelation } \\
\hline & & & & $\rho_{1}$ & $\rho_{2}$ & $\rho_{3}$ & $\rho_{4}$ & $\rho_{12}$ & $\rho_{24}$ \\
\hline$\overline{\mathrm{USD}^{\mathrm{b}}}$ & 0.0337 & 0.008 & 4.481 & $0.948 *$ & $0.886 *$ & $0.828 *$ & $0.792 *$ & $0.506^{*}$ & $0.454^{*}$ \\
\hline $\mathrm{TB}$ & 0.0055 & 0.007 & 0.775 & $0.209 *$ & 0.107 & -0.116 & $-0.161 *$ & 0.153 & 0.021 \\
\hline Bond & 0.0132 & 0.005 & 2.803 & $0.949 *$ & $0.870 *$ & $0.822 *$ & $0.798 *$ & $0.529 *$ & $0.400 *$ \\
\hline
\end{tabular}

Table 1c. Summary statistics for the market returns and instrumental variables: unconditional correlation of the market returns

\begin{tabular}{llllllll}
\hline Market & HK & JP & KO & MY & TH & US & World \\
\hline Hong Kong & 1 & 0.272 & 0.141 & 0.493 & 0.336 & 0.302 & 0.416 \\
Japan & & 1 & 0.337 & 0.291 & 0.168 & 0.293 & 0.729 \\
Korea & & & 1 & 0.176 & 0.032 & 0.136 & 0.251 \\
Malaysia & & & & 1 & 0.467 & 0.357 & 0.432 \\
Thailand & & & & & 1 & 0.322 & 0.339 \\
USA & & & & & & 1 & 0.577 \\
World & & & & & & & 1 \\
\hline
\end{tabular}

Notes: ${ }^{\mathrm{a}} \mathrm{HK}$ (Hong Kong), JP (Japan), KO (Korea), MY (Malaysia), and TH (Thailand).

${ }^{\mathrm{b}}$ USD (US dividend yield), TB (Treasury Bill yield spread) and Bond (bond yield spread).

* Significance at the 5\% level based on an approximate standard deviation of $1 /(o b s)^{1 / 2}$, where $o b s$ is the usable observations. 
the means, standard deviations, reward to risk ratios, and autocorrelation of excess equity returns. The average country's equity returns range from $0.38 \%$ for the USA to $1.58 \%$ for Hong Kong. All the equity returns of the five Asia Pacific markets were higher than those of the US and world market. However, the high returns are accompanied by high standard deviations. If the average returns are compared to the standard deviations, the reward to risk ratios of the five Asia Pacific markets are still above those of the US and the world market. Each of the five high reward to risk ratio may reflect the capital gain during the time of market opening and the booming economy.

The equity returns from two countries (Malaysia and Thailand) display a significant first order autocorrelation. Bessembinder and Chan (1995) have shown that technical analysis could predict movements in Malaysia and Thailand, so it is no wonder that these two markets exhibited high first order autocorrelation. The Korean return has a very low first order autocorrelation, but shows a significant second order autocorrelation. No other countries and the world portfolio exhibit a significant timeseries pattern.

All of the three instrumental variables (US dividend yield, Treasury Bill yield spread, and Bond yield spread) exhibit significant first order autocorrelation in Panel B. In addition, the high order autocorrelation of the US dividend yield and bond yield spread decay exponentially, which correspond to autoregressive process. The autoregressive pattern was expected for the dividend yield owing to its method of construction, which is a moving average. The bond Baa and Aaa move the same way, because the spread between them also display high autocorrelation for long lag.

The unconditional correlation matrix for equity returns is shown in Panel C. Most equity returns from the Asian Pacific were generally less correlated with the world market than the USA was. The low correlations suggest that significant benefits can be gained from diversifying into these markets. Among the Asian Pacific markets, only Japan exhibited more than a 0.5 correlation with the MSCI world return. The USA shows a 0.58 correlation with the MSCI world return. These two high correlations for Japan and the USA can be easily seen from the weight contained in the MSCI world index, $42.9 \%$ and 30\% in March 1989 , respectively. A more detailed examination of the other time-series properties of the data is made in the Appendix.

\section{EMPIRICAL RESULTS}

\section{Principal component analysis}

In order to determine the most important common factors that influence the interest rates of countries in the Asian Pacific, a principal component analysis is taken of the excess return on the currency deposit of those five Asian Pacific countries. The last column of Table 2 displays the total variance captured by the principal components. The first two principal components explain $80 \%$ of the total variance; these components will be priced in the next subsection. The first component may be seen as a weighted

Table 2. Principal component analysis for country's interest rate

Five Asian Pacific countries' interest rates: Hong Kong, Korea, Japan, Malaysia, and Thailand, are taken to form the principal components. The interest rates are the one-month interest rate of that currency compounded by the rate of change of the exchange rate relative to the US dollar, minus the dollar one-month risk-free rate.

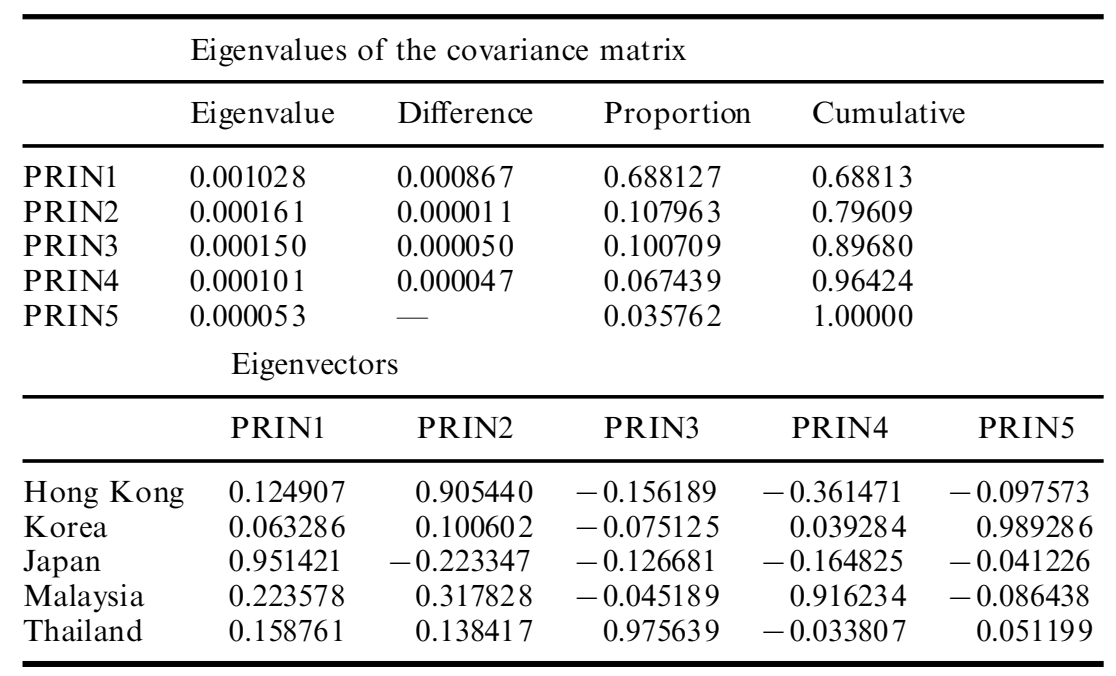

Note: Total variance $=0.0014940645$ 
average of the excess return of those five countries' currency deposits, where the excess return of Japan has the highest weight. This result is also supported by the work of Ferson and Harvey (1993), which used the relative shares of the total real gross domestic product (GDP) as the weights for the global inflation measure. In contrast to the first component, the second component assign Japan a negative weight.

\section{Testing the conditional asset pricing model}

The classic APM was examined as well as the international APM. The formulations of these two models were shown in Equation 8. The foreign exchange risk was priced in the international APM, while it was not priced in the classic APM.

Panel A of Table 3 displays the results of testing the conditional classic APM. Six countries were examined: five Asian Pacific equity markets and the USA. There are 42 orthogonality conditions and 6 parameters, which implies that there are 36 overidentifying conditions. The $J$ test of the overidentifying restrictions has a $p$-value of 0.1182 . Hence, this classic model was not rejected during the sample period. The time-varying world price of risk was created by the instrumental variables and the constant parameters. Three of the six parameters were different from zero at a $5 \%$ significance level. Lack of rejection implies that the conditional classic APM can still capture the

Table 3a. Estimation of the conditional classic and international APM: conditional classic APM

For classic, the following equations are estimated by GMM

$$
\begin{aligned}
e_{t} & =z_{t-1} \delta_{m} r_{m t} \\
h_{i t} & =r_{i t}-r_{i t} e_{t}
\end{aligned}
$$

For international, the following equations are estimated by GMM

$$
\begin{aligned}
e_{t} & =\sum_{j=1}^{L} z_{t-1} \delta_{j} r_{j t}+z_{t-1} \delta_{m} r_{m t} \\
h_{i t} & =r_{i t}-r_{i t} e_{t}
\end{aligned}
$$

There are six equity markets, which are Hong Kong, Korea, Japan, Malaysia, Thailand, and the USA, to be examined.

\begin{tabular}{lllllll}
\hline Parameters & Constant & $\begin{array}{l}\text { Lag world } \\
\text { return }\end{array}$ & $\begin{array}{l}\text { Lag US } \\
\text { dividend }\end{array}$ & $\begin{array}{l}\text { Lag TB } \\
\text { spread }\end{array}$ & $\begin{array}{l}\text { Lab bond } \\
\text { spread }\end{array}$ & January \\
\hline Coefficient & -11.072 & 233.990 & 779.274 & -674.938 & -731.462 & -1.088 \\
$(t$-statistics $)$ & $(-1.479)$ & $(6.062)^{*}$ & $(1.984)^{*}$ & $(-3.156)^{*}$ & $(-1.094)$ & $(-0.215)$ \\
\hline
\end{tabular}

Notes: The number of orthogonality conditions $=42$.

The number of parameters $=6$.

The number of overidentifying restrictions $=36$.

$\chi^{2}(36)=46.2267, p$-value $=0.1182$.

* Significance at the $5 \%$ level.

Table 3b. Estimation of the conditional classic and international APM: conditional international APM

\begin{tabular}{lcccccc}
\hline Parameters & Constant & $\begin{array}{l}\text { Lag world } \\
\text { return }\end{array}$ & $\begin{array}{l}\text { Lag US } \\
\text { dividend }\end{array}$ & $\begin{array}{l}\text { Lag TB } \\
\text { spread }\end{array}$ & $\begin{array}{l}\text { Lab bond } \\
\text { spread }\end{array}$ & January \\
\hline World & 41.248 & 295.091 & -648.114 & -149.038 & -1191.449 & 20.799 \\
$(t$-statistics $)$ & $(1.948)$ & $(3.618)^{*}$ & $(-0.523)$ & $(-0.209)$ & $(-0.601)$ & $(1.352)$ \\
Prin 1 & -86.098 & -154.555 & 2264.091 & -903.475 & 1117.837 & -80.774 \\
$(t$-statistics $)$ & $(-3.318)^{*}$ & $(-1.475)$ & $(1.715)$ & $(-1.377)$ & $(0.527)$ & $(-2.938)^{*}$ \\
Prin2 & 38.563 & 1175.972 & 4861.746 & -9100.194 & -11706.94 & 13.315 \\
$(t$-statistics $)$ & $(0.433)$ & $(2.143)^{*}$ & $(1.097)$ & $(-2.259)^{*}$ & $(-2.081)^{*}$ & $(0.118)$ \\
\hline
\end{tabular}

Notes: The number of orthogonality conditions $=42$.

The number of parameters $=18$.

The number of overidentifying restrictions $=24$.

$\chi^{2}(24)=22.5048, p$-value $=0.5492$.

* Significance at the $5 \%$ level. 
dynamics of returns on these equity markets, and is consistent with the findings of Harvey (1991) for MSCI indices of industrialized countries.

Panel B of Table 3 displays the results of the conditional version of the international APM. With 42 orthogonality conditions and 18 parameters, there are 24 overidentifying restrictions. The $p$-value of the $J$ test is equal to 0.5492 , which was not rejected by the data. Six of the eighteen parameters were distinct from zero at a 5\% significance level.

To compare these two models which were not rejected, a more robust test was needed for examining the existence of the prices of foreign exchange risk for the Pacific Basin equity markets. The classic APM can be tested against the international APM because these two models are nested. Following Newey-West (1987), the international APM was estimated first; then, the classic APM was estimated using the weighting matrix of the unconstrained model, which was the international APM. The difference between the constrained and unconstrained $\chi^{2}$ was distributed to $\chi^{2}$ with 12 degrees of freedom. The result is reported in Panel A of Table 4, which shows that the constrained $\chi^{2}$ is much higher than the unconstrained $\chi^{2}$. Therefore, it can be concluded that the time-varying prices of foreign exchange risk were present for the Pacific Basin equity markets during the sample period. The empirical result was consistent with the evidence of Harvey et al. (1994) for OECD countries, where one risk premium was not sufficient to characterize the variation in expected returns, and there existed another premium, which was related to foreign exchange risk.

Table 4 also shows the results of testing whether the prices of market risk and foreign exchange risk are timevarying or not. In Panel B, the Newey-West test is used to examine the null hypothesis of the time-invariant world price of market risk against the alternative of a timevarying one. The hypothesis of the time-invariant world price of market risk is rejected. In Panel C, the timeinvariant prices of exchange risk are also tested by the Newey-West test. The $p$-value, which was extremely small, rejects the null hypothesis. Again, time-varying prices of exchange risk are suitable for these Pacific Basin equity markets. The finding is consistent with many empirical tests, e.g., Dumas and Solnik (1995) and Engel and Rodrigues (1989).

\section{The projection of world price of risk}

The evidence of time-varying world price of risk can be explained in that Pacific Basin countries experienced many changes in their economies during the sample period, including reduced capital control, liberalized exchange rates, and high rates of economic growth. Figure 1 displays the time variations of the world prices of market risk and exchange risk, which were projected by the instrumental

Table 4a. Hypothesis test: Testing classic APM against international APM

The following equations are examined by GMM and Newey-West test

$$
\begin{aligned}
e_{t} & =\sum_{j=1}^{L} z_{t-1} \delta_{j} r_{j t}+z_{t-1} \delta_{m} r_{m t} \\
h_{i t} & =r_{i t}-r_{i t} e_{t}
\end{aligned}
$$

\begin{tabular}{llllll}
\hline $\begin{array}{l}\text { Null: } \\
\delta_{j}=0\end{array}$ & $\begin{array}{l}\text { Alternative: } \\
\text { at least one } \delta_{j} \neq 0\end{array}$ & Difference & $\begin{array}{l}\text { Degrees of } \\
\text { freedom }\end{array}$ & $P$-value \\
\hline$\chi^{2}$ & 65.1550 & 22.5048 & 42.6501 & 12 & 0.0000 \\
\hline
\end{tabular}

Table 4b. Hypothesis test: Testing time-invariant price of market risk against time-variant

\begin{tabular}{llllll}
\hline $\begin{array}{l}\text { Null: } \lambda_{m} \\
\text { time-invariant }\end{array}$ & $\begin{array}{l}\text { Alternative: } \lambda_{m} \\
\text { time-variant }\end{array}$ & Difference & $\begin{array}{l}\text { Degrees of } \\
\text { freed om }\end{array}$ & $P$-value \\
\hline$\chi^{2}$ & 46.6645 & 22.5048 & 24.1597 & 5 & 0.0002 \\
\hline
\end{tabular}

Table 4c. Hypothesis test: Testing time-invariant price of exchange risk against time-variant

\begin{tabular}{lllccc}
\hline $\begin{array}{l}\text { Null: } \lambda_{j} \\
\text { time-invariant }\end{array}$ & $\begin{array}{l}\text { Alternative: } \lambda_{j} \\
\text { time-variant }\end{array}$ & Difference & $\begin{array}{l}\text { Degress of } \\
\text { freedom }\end{array}$ & $P$-value \\
\hline$\chi^{2}$ & 63.2813 & 22.5048 & 40.7764 & 10 & 0.0000 \\
\hline
\end{tabular}



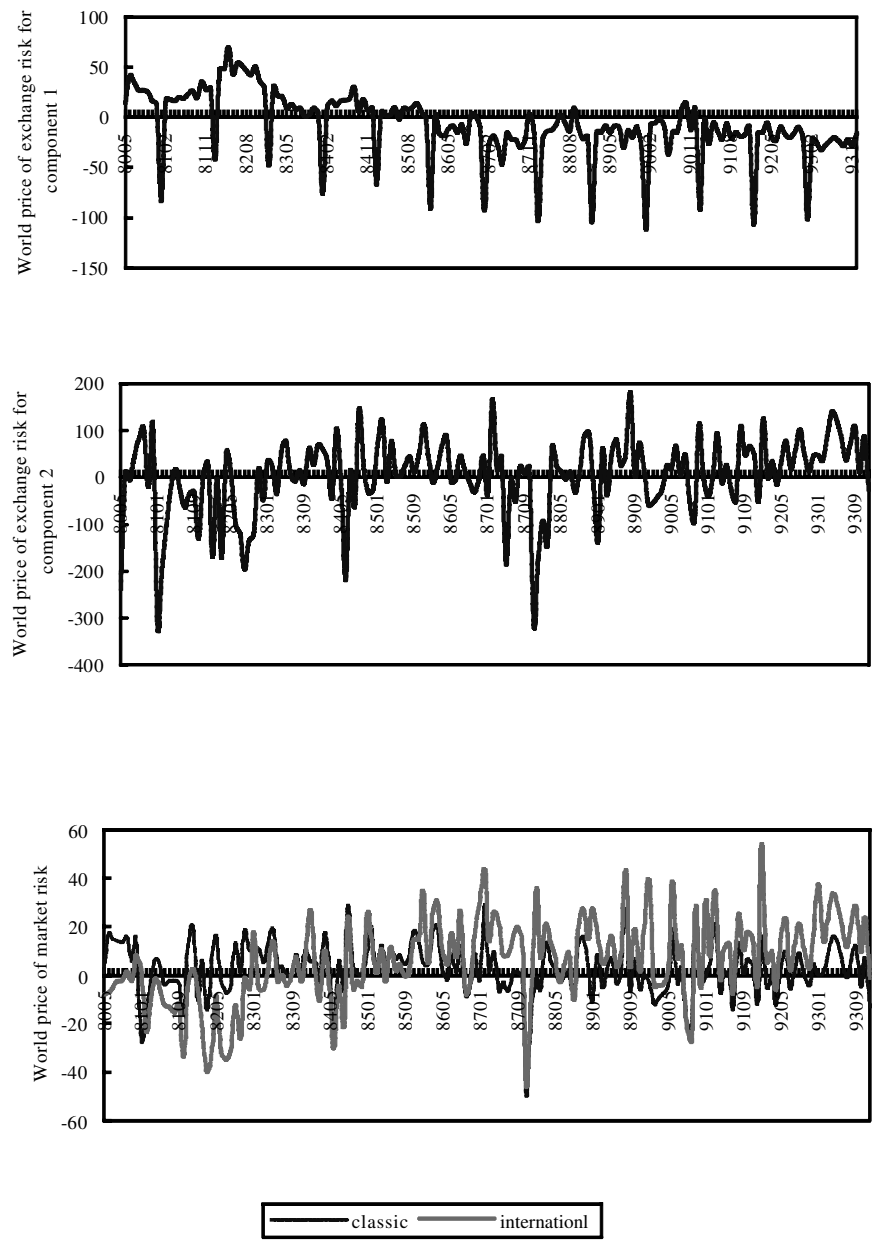

Fig. 1. The projection of the world price of risk

The time variations of the world prices of market risk and exchange risk are projected by the instrumental variables, including the world market return, the S\&P500 dividend yield, the US yield spread between Moody's Baa and Aaa bonds, the excess return on a three month bill, and a dummy variable for the month of January.

variables. The prices of market risk under the classic and international APM vary in an almost identical fashion, but not of the same magnitude. The magnitude of volatility of the price of market risk under the classic is smaller than the international. The addition of foreign exchange risk plays an important role in estimating the price of market risk. It is interesting to observe that the world price of exchange risk is more volatile than the world price of market risk. For the world price of component 1 exchange risk, there is a significant January effect towards negative. The negative world price of exchange risk is not surprising. Dumas and Solnik (1995) indicated that the world prices of exchange risk should be negative when the risk aversion of each investor subpopulation is greater than 1 . The January effect is more noteworthy, however. ${ }^{6}$

In the international APM of Adler and Dumas (1983), they had argued that there were two hypotheses to be tested: (1) the regression coefficients, which are the prices of risk, on all the covariance terms add up to one; (2) the coefficient on the covariance with the market is positive. The prices of risk in the present model are time-varying and fluctuate between positive and negative values, so the average value is used to inspect the values of the world price of risk. On average, the world price of market risk is positive, but all the prices of risk do not sum to one. There may be some other factors that influence the risk premia in the Pacific Basin equity markets, such as political intervention. Although most Pacific Basin countries have had their capital markets open for a long time, there still remain some limits on foreign investors under certain regulations. These restrictions may limit these markets from becoming fully integrated into the world capital market. As a result, an asset pricing model with time-varying integration may be proper to capture the dynamics of risk premia for Pacific Basin capital markets. ${ }^{7}$

\section{CONCLUSION}

Five Asian Pacific as well as the US equity markets were examined by the conditional APM. A principal component analysis is taken to extract the common factors that influence those Asian Pacific interest rates. Both of classic and international APM were examined, where the exchange risk was priced in the international APM and was not priced in the classic APM. The world prices of market risk and exchange risk were allowed to vary over time with common market information variables.

Using the GMM estimation and the $J$ test, both models, classic and international, were not rejected. However, using a more robust test, the Newey-West test, the null hypothesis of the classic APM was rejected against the international APM. Moreover, the null hypotheses of timeinvariant prices of market risk and exchange risk were rejected against the time-variant. These results suggest

\footnotetext{
${ }^{6}$ The unreasonable values for the world prices of risk may result from model misspecification or improper simplifying assumptions; see Glassman and Riddick (1996).

${ }^{7}$ The test of time-varying world market integration had been explored by Bekaert and Harvey (1995). They found that a number of emerging markets exhibit time-varying integration.
} 
that the conditional classic APM can still capture the dynamics of the returns on the Pacific Basin equity markets, but the exchange risk should be priced to get a more explanatory power. In addition, the world prices of market risk and exchange risk are time-varying conditional on some common market information variables during the sample period.

The results imply that the exchange risk cannot be fully diversified away in the Pacific Basin equity markets. Hence, active hedging policies might be needed to gain the diversified benefits of investing into these markets.

\section{ACKNOWLEDGEMENT}

The authors wish to thank the editor and an anonymous reviewer for their helpful comments and suggestions on an earlier version of this paper.

\section{REFERENCES}

Adler, M. and Dumas, B. (1983) International portfolio choice and corporation finance: a synthesis, Journal of Finance, 38, 925-84.

Bekaert, G. and Harvey, C. R. (1995) Time-varying world market integration, Journal of Finance, 50, 403-44.

Bessembinder, H. and Chan, K. (1995) The profitability of technical trading rules in the Asian stock markets, Pacific-Basin Finance Journal, 3, 257-84.

Cumby, R. E. (1990) Consumption risk and international equity returns: some empirical evidence, Journal of International Money and Finance, 9, 182-92.

Davidson, R. and Mackinnon, J. G. (1993) Estimation and Inference in Econometrics, Oxford University Press, New York.

Dumas, B. (1994) A test of the international CAPM using business cycles indicators as instrumental variables, National Bureau of Economic Research (NBER) Working Paper No. 4657.

Dumas, B. and Solnik, B. H. (1995) The world price of foreign exchange risk, Journal of Finance, 50, 445-79.

Engel, C. and Rodrigues, A. P. (1989) Tests of international CAPM with time-varying covariances, Journal of Applied Econometrics, 4, 119-38.

Ferson, W. E. and Foerster, S. R. (1994) Finite sample properties of the generalized method of moments in tests of conditional asset pricing models, Journal of Financial Economics, 36, 2955.

Ferson, W. E. and Harvey, C. R. (1993) The risk and predictability of international equity returns, Review of Financial Studies, 6, 527-66.

Glassman, D. A. and Riddick, L. A. (1996) Why empirical international portfolio models fail: evidence that model misspecification creates home asset bias, Journal of International Money and Finance, 15, 275-12.

Hansen, L. P. (1982) Large sample properties of generalized method of moments estimators, Econometrica, 50, 1029-54.

Hansen, L. P. and Jagannathan, R. (1991) Implications of security market data for models of dynamic economies, Journal of Political Economy, 99, 225-61.

Harvey, C. R. (1991) The world price of covariance risk, Journal of Finance, 46, 111-57.
Harvey, C. R. (1995) Predictable risk and returns in emerging markets, Review of Financial Studies, 8, 773-816.

Harvey, C. R., Solnik, B. and Zhou, G. (1994) What determines expected international asset returns? NBER Working Paper No. 4660.

Harvey, C. R. and Zhou, G. (1993) International asset pricing with alternative distributional specifications, Journal of Empirical Finance, 1, 107-131.

Lucas, R. E. (1982) Interest rates and currency prices in a twocountry world, Journal of Monetary Economics, 10, 335-60.

Newey, W. K. and West, K. D. (1987) Hypothesis testing with efficient method of moments estimation, International Economic Review, 28, 777-87.

Perold, A. F. and Schulman, E. C. (1988) The free lunch in currency hedging: Implications for investment policy and performance standards, Financial Analysts Journal, 44, 4550.

Phillips, P. C. B. and Perron, P. (1988) Testing for a unit root in time series regression, Biometrika, 75, 335-46.

Shapiro, S. S. and Wilk, M. B. (1965) An analysis of variance test for normality (complete samples), Biometrika, 52, 591-611.

Solnik, B. H. (1974a) An equilibrium model of the international capital market, Journal of Economic Theory, 8, 500-24.

Solnik, B. H. (1974b) The international pricing of risk: An empirical investigation of the world capital market structure, Journal of Finance, 29, 365-78.

Solnik, B. H. (1983) International arbitrage pricing theory, Journal of Finance, 38, 449-57.

Stehle, R. (1977) An empirical test of the alternative hypotheses of national and international pricing of risky assets, Journal of Finance, 32, 493-502.

Stulz, R. (1981) A model of international asset pricing, Journal of Financial Economics, 9, 383-406.

Stulz, R. (1994) International portfolio choice and asset pricing: an integrative survey, NBER Working Paper No. 4645.

Thomas, S. H. and Wickens, M. R. (1993) An international CAPM for bonds and equities, Journal of International Money and Finance, 12, 390-412.

Wheatley, S. (1988) Some tests of international equity integration, Journal of Financial Economics, 21, 177-212.

\section{APPENDIX}

Table A1 reports some additional statistics and unit root tests for the data. The skewness statistics are almost consistent with symmetry, but the kurtosis statistics are significant deviations from zero for most data. From the $W$ statistic of Shapiro and Wilk (1965), only the world portfolio and Malaysia are not rejected at a $5 \%$ significance level. This implies that most data are unlikely to be generated from a normal distribution.

The rest of Table A1 shows the result of detecting the presence of a unit root in the data. Phillips-Perron (1988) was used to test the null hypothesis of the existence of a unit root, because this test allows weakly dependent and heterogeneously distributed errors. Most tests provide significant evidences of rejection of the unit root except the US dividend yield spread and bond yield spread. While the US dividend yield spread is not rejected when the test includes constant and trend terms with truncation at lag 
Table A1. Other summary statistics and unit root tests

\begin{tabular}{|c|c|c|c|c|c|c|c|c|c|c|}
\hline Statistic & $\mathrm{WR}^{\mathrm{a}}$ & US & USD & TB & Bond & $\mathrm{HK}$ & $\mathrm{KO}$ & JP & MY & TH \\
\hline & -0.402 & -0.458 & 0.980 & 1.926 & 20 & -0.917 & 0.692 & 0.410 & -0.308 & -0.159 \\
\hline Kurtosis & 1.727 & 2.577 & 0.447 & 4.694 & 0.286 & 3.740 & 0.408 & 1.232 & 2.282 & 3.430 \\
\hline$W^{\mathrm{b}}$ & 0.984 & $0.963^{*}$ & $0.902 *$ & $0.820 *$ & $0.911 *$ & $0.963 *$ & $0.958 *$ & $0.970 *$ & 0.985 & $0.949 *$ \\
\hline$\tau_{\mathrm{nc}}(1)^{\mathrm{c}}$ & $-154.8^{*}$ & $-114.7^{*}$ & $-8.23 *$ & $-130.1^{*}$ & $-9.29 *$ & $-148.5^{*}$ & $-164.2 *$ & $-149.7^{*}$ & $-131.0 *$ & $-125.9 *$ \\
\hline$\tau_{\mathrm{nc}}(2)$ & $-155.9 *$ & $-113.4^{*}$ & $-8.63 *$ & $-134.6^{*}$ & $-8.45^{*}$ & $-144.1 *$ & $-174.2 *$ & $-148.9 *$ & $-135.7^{*}$ & $-131.1 *$ \\
\hline$\tau_{\mathrm{nc}}(3)$ & $-155.4^{*}$ & $-108.3^{*}$ & $-8.62 *$ & $-132.4^{*}$ & -7.68 & $-141.9^{*}$ & $-176.7^{*}$ & $-149.0 *$ & $-135.8 *$ & $-134.1 *$ \\
\hline$\tau_{\mathrm{nc}}(4)$ & $-154.6^{*}$ & $-105.1 *$ & $-8.62 *$ & $-127.9 *$ & -7.41 & $-137.0 *$ & $-180.9 *$ & $-150.3^{*}$ & $-136.1^{*}$ & $-132.2 *$ \\
\hline$\tau_{\mathrm{nc}}(8)$ & $-163.6^{*}$ & $-102.9 *$ & $-9.42 *$ & $-119.4^{*}$ & -7.35 & $-128.2^{*}$ & $-198.2 *$ & $-156.3^{*}$ & $-138.3^{*}$ & $-123.6^{*}$ \\
\hline$\tau_{\mathrm{nc}}(12)$ & $-171.8 *$ & $-96.5^{*}$ & $-9.48 *$ & $-124.0^{*}$ & -7.06 & $-133.6^{*}$ & $-218.0 *$ & $-169.5^{*}$ & $-141.0^{*}$ & $-129.8 *$ \\
\hline$\tau_{\mathrm{ct}}(1)$ & $-154.8 *$ & $-114.8^{*}$ & -18.63 & $-132.3^{*}$ & $-30.03 *$ & $-149.7^{*}$ & $-164.2 *$ & $-150.5^{*}$ & $-132.4^{*}$ & $-129.4^{*}$ \\
\hline$\tau_{\mathrm{ct}}(2)$ & $-155.9 *$ & $-113.4^{*}$ & -20.02 & $-136.8 *$ & $-28.35^{*}$ & $-144.7^{*}$ & $-174.2 *$ & $-149.6^{*}$ & $-136.6^{*}$ & $-134.3^{*}$ \\
\hline$\tau_{\mathrm{ct}}(3)$ & $-155.3^{*}$ & $-108.3^{*}$ & -20.24 & $-134.2^{*}$ & $-26.71 *$ & $-141.6^{*}$ & $-176.7 *$ & $-149.7 *$ & $-136.1^{*}$ & $-136.7 *$ \\
\hline$\tau_{\mathrm{ct}}(4)$ & $-154.5^{*}$ & $-105.1 *$ & -20.49 & $-129.1^{*}$ & $-26.51 *$ & $-135.9 *$ & $-180.9 *$ & $-151.0 *$ & $-135.7^{*}$ & $-134.1 *$ \\
\hline$\tau_{\mathrm{ct}}(8)$ & $-163.5^{*}$ & $-102.8^{*}$ & $-23.32 *$ & $-118.2^{*}$ & $-27.73 *$ & $-123.6^{*}$ & $-198.4 *$ & $-156.6^{*}$ & $-135.4^{*}$ & $-122.5^{*}$ \\
\hline$\tau_{\mathrm{ct}}(12)$ & $-171.6^{*}$ & $-96.2 *$ & $-23.63^{*}$ & $-121.3^{*}$ & $-26.70^{*}$ & $-125.6^{*}$ & $-218.5^{*}$ & $-169.2^{*}$ & $-135.3^{*}$ & $-126.4^{*}$ \\
\hline
\end{tabular}

Notes: ${ }^{\mathrm{a}}$ WR (world portfolio), USD (US Dividend Yield), TB (Treasury Bill yield spread), Bond (bond yield spread), HK (Hong Kong), KO (Korea), JP (Japan), MY (Malaysia), and TH (Thailand).

${ }^{\mathrm{b}} W$ statistic is based on Shapiro and Wilk (1965), which is a test of null hypothesis of normal distribution.

${ }^{\mathrm{c}} \tau_{\mathrm{nc}}(1)$ are the Phillips-Perron test for a unit root, where nc represents non-constant and non-trend, ct denotes constant and trend, and the number in parentheses is the lag truncation parameters. The significance level is based on asymptotic critical values in Page 708 of Davidson and Mackinnon (1993).

* Significance at $5 \%$ level.

$1,2,3$, and 4 at a 5\% significance level, these tests are rejected at a $10 \%$ level. The tests of the bond yield spread are not rejected when they do not include constant and trend terms with truncation at lag $3,4,8$, and 12 at a 5\% significance level, but they are also rejected at a $10 \%$ level. As a result, it is hard to conclude that these two series are generated from a random walk process. The other series could be characterized as integrated of order zero, i.e., $I(0)$. 